\title{
Sistem Pendukung Pengambilan Keputusan Karyawan Terbaik Menggunakan Metode Simple Additive Weighting (SAW) Pada PT Nippon Indosari Corpindo Tbk Plant Cibitung
}

The Best Employee Decision Support System Using the Simple Additive Weighting (SAW) Method at PT Nippon Indosari Corpindo Tbk Plant Cibitung

\author{
Dede Cahyana ${ }^{1}$, Eko Martantoh ${ }^{2}$ \\ ${ }^{1,2}$ Program Studi Sistem Informasi, Universitas Panca Sakti, Bekasi \\ E-mail: ${ }^{1}$ dcahyana26@gmail.com, ${ }^{2}$ ekomartantoh@gmail.com
}

\begin{abstract}
Abstrak
Manajemen SDM (Sumber Daya Manusia) dari perusahaan sangat mempengaruhi banyak aspek penentu keberhasilan kerja perusahaan. Salah satu proses yang sangat penting dalam Departemen SDM suatu perusahaan yaitu penilaian kinerja. Secara umum, penilaian itu diberikan oleh rekomendasi atasan unit kerja masing-masing berdasarkan masa kerja, penilaian kinerja dan penilaian perilaku karyawan dalam melaksanakan tugasnya. Untuk itu maka diperlukan penilaian karyawan yang dapat membantu memfasilitasi pengawas dan Departemen SDM untuk mengambil keputusan yang berkaitan dengan kinerja karyawan. Saat ini pengolahan data penilaian karyawan perusahaan masih dilakukan dengan komputerisasi excel, sehingga semakin besar resiko kesalahan memasukkan data mengingat jumlah karyawan sangat banyak dan dibutuhkan waktu yang relatif lama. Metode yang digunakan dalam menentukan karyawan terbaik ini adalah Simple Additive Weight (SAW). Di mana metode ini adalah metode penghitungan tertimbang atau metode yang menyediakan kriteria tertentu yang berbobot sehingga setiap nilai jumlah dari bobot dan hasil yang diperoleh akan menjadi keputusan akhir. Dilihat dari aspek manajerial, penilaian dapat dikembangkan dengan kriteria lain sesuai dengan kebutuhan perusahaan. Perhitungan menggunakan metode SAW, dengan mengacu pada kriteria pekerjaan, evaluasi kinerja, dan penilaian perilaku karyawan, kemudian memilih seorang karyawan terbaik.
\end{abstract}

Kata kunci: SAW, UML, Php, mysql, Algoritm

\begin{abstract}
HR management (Human Resources) of the company greatly influences many aspects of determining the success of the company's work. One of the most important processes in the Department HR of a company is performance appraisal. In general, the assessment is given by the recommendations of the superiors of each work unit based on years of service, performance appraisal and employee behavior assessment in carrying out their duties. For this reason, an employee assessment is needed that can help facilitate supervisors and the Department HR to make decisions related to employee performance. Currently the company's employee assessment data processing is still done by computerized excel, so the greater the risk of entering data errors considering the number of employees is very large and it takes a relatively long time. The method used in determining the best employees is Simple Additive Weight (SAW). Where this method is a weighted calculation method or a method that provides certain criteria that are weighted so that each value of the sum of the weights and the results obtained will be the final decision. Viewed from the managerial aspect, the assessment can be developed with other criteria according to the needs of the company. The calculation uses SAW method, with reference to job criteria, performance evaluation, and employee behavior assessment, then chooses the best employee.
\end{abstract}

Keyword: SAW, UML, Php, mysql, Algorithm 


\section{PENDAHULUAN}

Penilaian karyawan yang berkualitas sangat dibutuhkan di setiap perusahaan untuk menunjang perkembangan dan kemajuan sebuah perusahaan[1], di PT Nippon Indosari Corpindo Tbk yang telah menerapkan HC (Human Capital) perusahaan harus lebih selektif dalam melakukan penilaian karyawan nya. Jika sebuah perusahaan salah dalam melakukan penilaian karyawan dapat merugikan karyawan yang bekerja pada perusahaan tersebut, dikarenakan penilaian karyawan berkaitan dengan kenaikan grade karyawan, penilaian karyawan juga diperlukan dalam rangka mengukur kinerja setiap karyawan atas prestasi kerja. Menurut Stolovitch and Keeps (dalam blog Mangkuprawira) Kinerja adalah seperangkat hasil yang dicapai dan merujuk pada tindakan pencapaian serta pelaksanaan sesuatu pekerjaan yang diminta [2].

SDM dari suatu perusahaan sangat mempengaruhi banyak aspek penentu keberhasilan kerja dari perusahaan tersebut. Salah satu proses yang sangat penting dalam Human Resources Departement (HRD) sebuah perusahaan atau badan usaha yaitu proses penilaian kinerja seorang karyawan, perusahaan akan mengetahui apakah target karyawan yang telah ditetapkan selama ini telah tercapai atau belum [3]. Persaingan para karyawan yang semakin ketat membuat sebuah keputusan karyawan terbaik semakin sulit untuk diputuskan, terutama jika ada beberapa karyawan yang memiliki kemampuan yang tidak jauh berbeda. Pengambilan keputusan yang tidak adil dapat menimbulkan dampak buruk bagi suatu perusahaan. Hal ini dapat menurunkan tingkat kinerja para karyawan pada perusahaan tersebut. Untuk itu diperlukan pengambilan keputusan yang tepat dan cermat untuk menentukan penilaian kinerja semua karyawan dalam sebuah perusahaan merupakan suatu tahap evaluasi kerja yang dapat meningkatkan kualitas pekerjaan bagi kelangsungan aktivitas perusahaan di dalamnya [4].

Pada umumnya penilaian karyawan diberikan atas rekomendasi atasan atau unit kerja masing-masing berdasarkan masa bekerja, penilaian kinerja dan penilaian perilaku seorang karyawan dalam menjalankan tugasnya. Untuk itu maka diperlukan pengolahan data penilaian karyawan yang dapat membantu mempermudah seorang atasan dan bagian HRD untuk mengambil sebuah keputusan yang berkaitan dengan penilaian seorang karyawan.

Saat ini pengolahan data penilaian karyawan di perusahaan tersebut masih dilakukan dengan komputerisasi excel, sehingga besar kemungkinan terjadinya kesalahan penginputan mengingat jumlah karyawan yang sangat banyak dan dibutuhkan waktu yang relatif lama. Selain itu juga masih sering terjadi informasi yang simpang siur mengenai pergerakan formasi karyawan.

Sistem pendukung keputusan atau decision support system (DSS) tidak dimaksudkan untuk mengotomatisasikan pengambilan keputusan, akan tetapi memberikan perangkat interaktif yang memungkinkan pengambil keputusan untuk melakukan berbagai analisis menggunakan model-model yang tersedia [5]. Metode yang digunakan dalam menentukan penilaian karyawan ini adalah metode SAW. Dimana metode ini merupakan metode pembilangan terbobot atau metode yang memberikan kriteria-kriteria tertentu yang memiliki bobot nilai masing-masing sehingga dari hasil penjumlahan bobot tersebut akan diperoleh hasil yang menjadi keputusan akhirnya. Penyelesaian masalah menggunakan metode SAW untuk menjabarkan bobot-bobot yang sesuai dengan kriteria yang pantas. Penilaian karyawan menggunakan cara manual membutuhkan banyak waktu untuk menentukan dengan banyak bobot yang dibutuhkan dalam penentuan karyawan terbaik sesuai dengan bidang masing-masing karyawan [6]. 
Dengan menerapkan manajemen SDM yang tepat dan benar, pihak manajemen perusahaan akan dapat mengarahkan karyawan secara benar sehingga potensinya berkembang. Lebih lanjut tujuan organisasi/perusahaan akan lebih mudah tercapai [7]. Salah satu proses pengambilan keputusan dalam perusahaan yaitu penentuan ranking karyawan terbaik. Seperti yang diketahui, karyawan merupakan komponen terpenting yang mempengaruhi keberhasilan dalam suatu pekerjaan. Semakin banyaknya jumlah karyawan yang berasal dari latar belakang pendidikan yang berbeda menjadikan keanekaragaman karyawan juga semakin kompleks sehingga sulit untuk memilih karyawan yang terbaik [8]. Pemilihan karyawan terbaik dapat dilakukan secara periodik sehingga yang terpilih akan diberikan penghargaan berupa bonus agar memotivasi karyawan dalam meningkatkan dedikasi dan kinerjanya [9], dan lainnya.

PT Nippon Indosari Corpindo Tbk adalah perusahaan yang bergerak dalam bidang industri, masih mengalami kendala penyeleksian dan penilaian karyawan terbaik seperti yang telah peneliti jelaskan di paragraf-paragraf sebelumnya. Berdasarkan penjelasan sebelumnya, maka peneliti mengambil judul "SISTEM PENDUKUNG PENGAMBILAN KEPUTUSAN KARYAWAN TERBAIK MENGGUNAKAN METODE SAW PADA PT NIPPON INDOSARI CORPINDO TBK".

Penulis membuat judul tersebut agar dapat di implementasikan pada perusahaan, karena pada system yang berjalan di PT Nippon Indosari Corpindo Tbk masih menggunakan cara konvensional. Judul ini juga yang memberikan motivasi belajar bagi penulis agar lebih kreatif, imajinatif langsung pada permasalahan di lapangan tempat penulis melakukan penelitian.

\section{METODE PENELITIAN}

Penelitian ini digambarkan menggunakan diagram alir atau flow chart, yang menggambarkan alur proses atau tahapan-tahapan penelitian mulai dari awal sampai selesai. Diagram alir digunakan untuk memudahkan pembaca untuk memahami metode penelitian yang dilakukan. Secara lengkap tahapan penelitian dapat dilihat pada Gambar 1. 


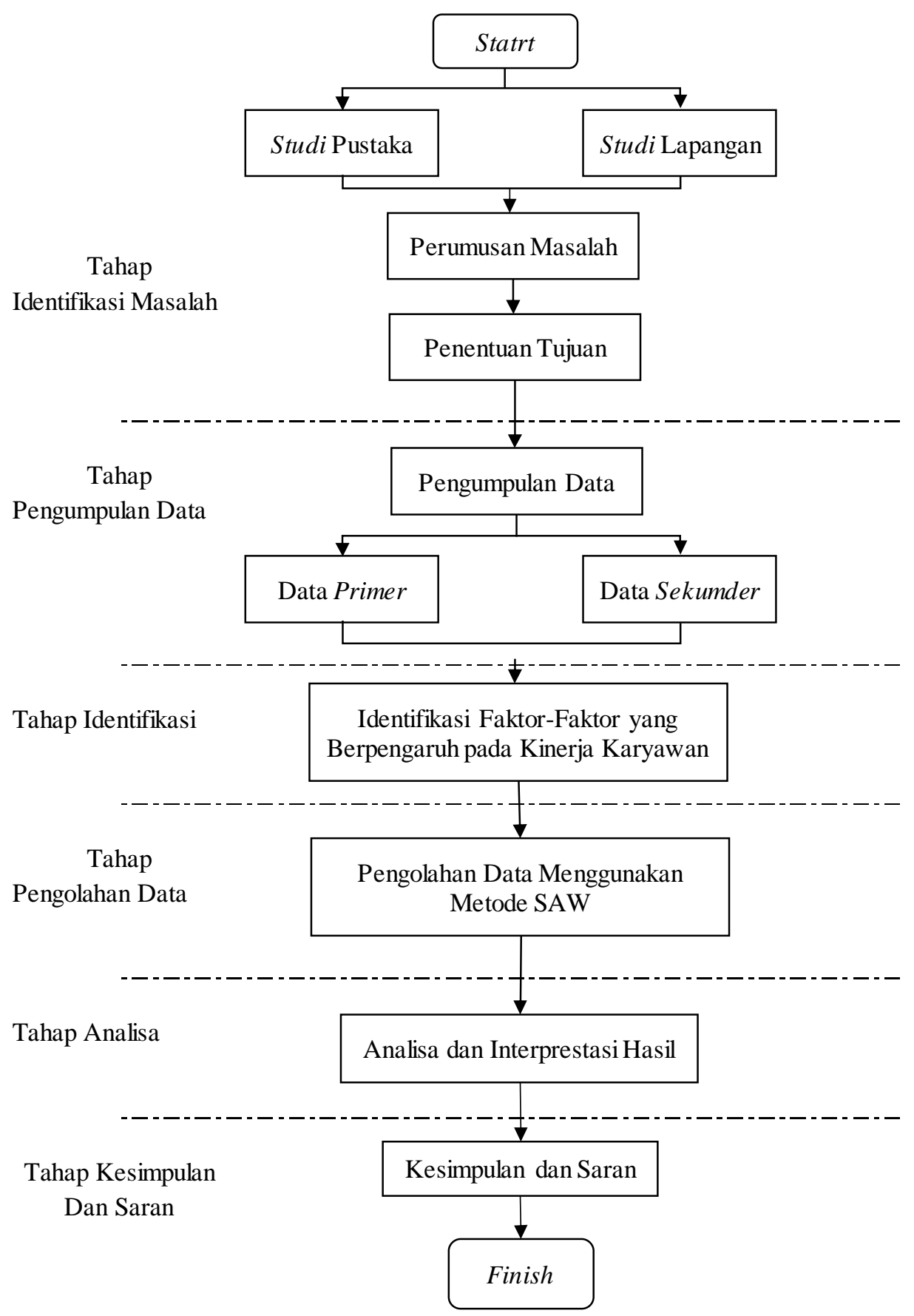

Gambar 1. Diagram Alir Penelitian

\subsection{Pengumpulan Data}

Pengumpulan data dilakukan dengan melakukan wawancara kepada pihak terkait pada PT Nippon Indosari Corpindo Tbk, observasi mengenai hal yang berhubungan dengan penilaian karyawan, dan melakukan studi literatur pada penelitian yang terkait dengan sistem pendukung keputusan.

\subsection{Identifikasi Masalah}

Tahap identifikasi masalah adalah cara dari peneliti untuk dapat menduga, memperkirakan dan menguraikan apa yang sedang menjadi masalah pada perusahaan. Identifikasi masalah dalam penelitian ini ada beberapa tahapan, antara lain: 
1. Studi lapangan

Tahap ini bertujuan untuk mengetahui kondisi real yang ada pada perusahaan, dengan diperolehnya gambaran tersebut diharapkan dapat mengetahui pendekatan yang sesuai dalam merancang suatu kerangka pengukuran kinerja karyawan dengan menggunakan metode SAW yang dapat diterapkan di perusahaan.

2. Studi pustaka

Tahap ini bertujuan untuk menunjang pencapaian tujuan pemecahan masalah dengan menggunakan pendekatan teori yang sesuai.

3. Perumusan Masalah

Setelah dilakukan studi pendahuluan, diperoleh fakta bahwa PT Nippon Indosari Corpindo Tbk membebaskan penilai dalam menilai kinerja karyawannya, hal ini dilakukan secara subyektif dengan beberapa pertimbangan, yaitu dari penglihatan dan ingatan atasan langsung. Sehingga penilaian karyawan dirasakan sebagai hal yang cukup kritis dalam proses mencari karyawan terbaik. Oleh karena itu dirumuskanlah permasalahan dalam penelitian ini yaitu bagaimana melakukan penilaian karyawan dengan mempertimbangkan berbagai kriteria menggunakan metode SAW.

4. Penentuan Tujuan

Tujuan dari penelitian ini adalah menentukan kriteria yang tepat bagi perusahaan dalam penilaian karyawan, serta menentukan karyawan secara tepat, dengan cara memilih karyawan dengan peringkat terbaik.

\subsection{Metode Pengolahan Data}

Pada tahap ini, pengolahan data dilakukan dalam dua tahapan, tahap pertama yaitu dengan menggunakan metode SAW. Untuk memudahkan dalam memahami pengolahan data yang dilakukan, berikut ini akan di tampilkan flowchart yang menggambarkan alur proses dari tahapan-tahapan pengolahan data mulai dari awal sampai selesai. Secara lengkap tahapan pengolahan data dapat dilihat pada Gambar 2.

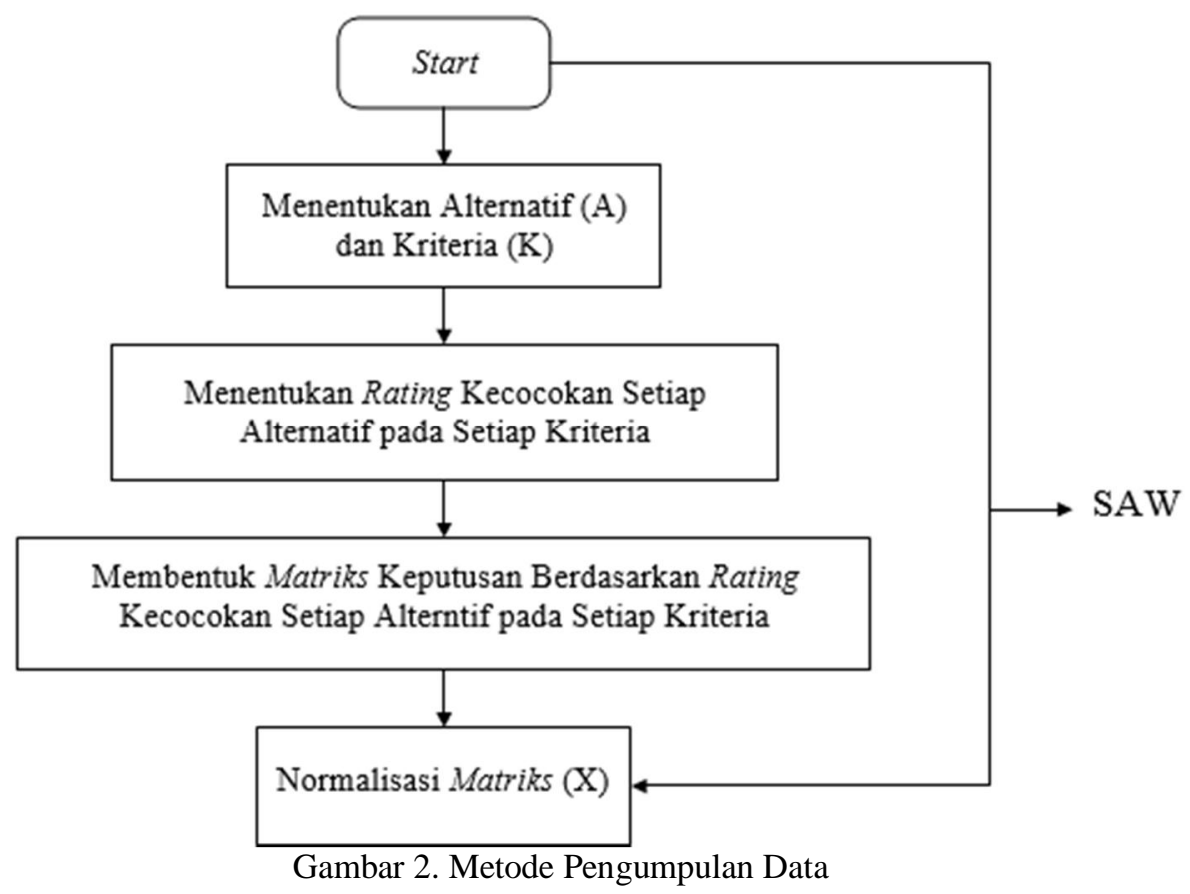




\subsection{Analisa}

Analisa yang dilakukan mulai dari awal yaitu mulai dari pengolahan data sampai dengan perangkingan calon karyawan terbaik. Berikut penjabaran hasil analisis pemilihan karyawan terbaik menggunakan metode SAW dapat dilihat pada Gambar 3.

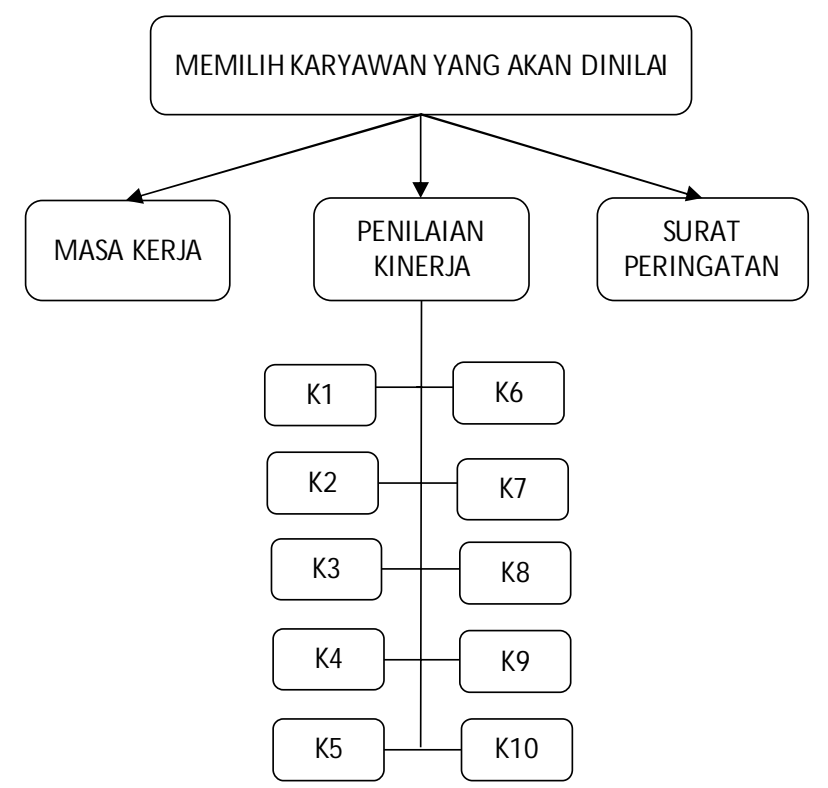

Gambar 3. Pemilihan Karyawan Menggunakan Metode SAW

Dari masing-masing kriteria tersebut akan ditentukan bobot-bobotnya, peneliti menentukan bobot berdasarkan hasil wawancara dan diskusi dengan administrasi pihak perusahaan.

\subsubsection{Use Case Diagram}

Analisis kebutuhan dari user serta kebutuhan dari sistem yang akan dibuat digambarkan dengan menggunakan use case diagram yang dapat dilihat pada Gambar 4 .

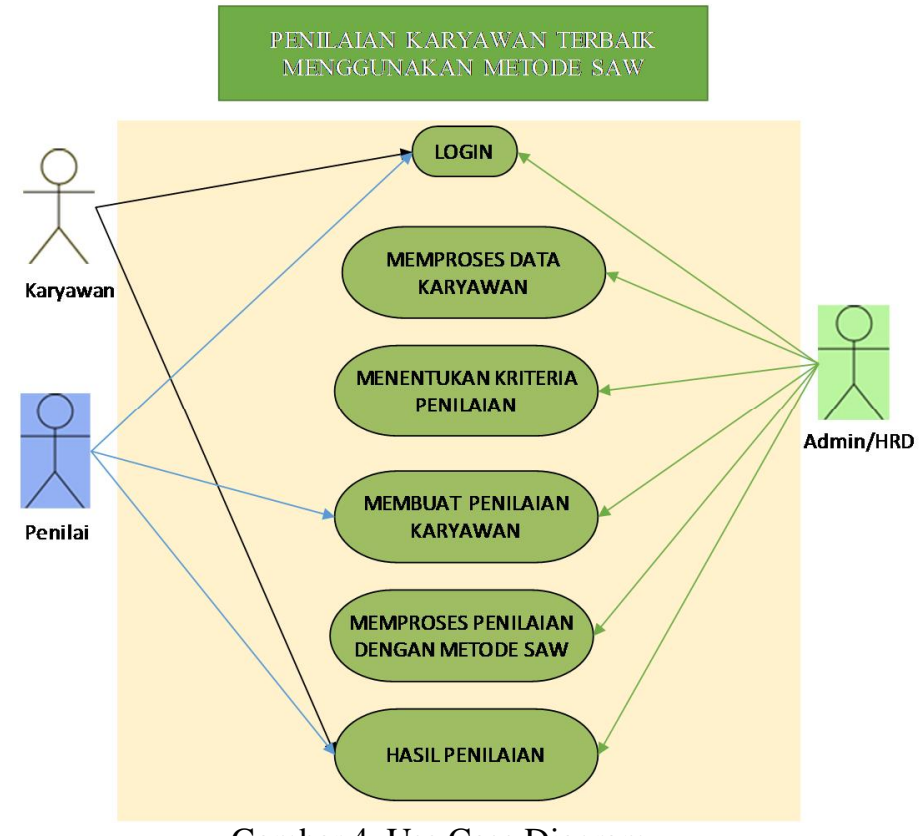

Gambar 4. Use Case Diagram 


\subsubsection{Entity Relationship Diagram (ERD)}

ERD yang di buat pada sistem ini dapat dilihat pada Gambar 5.

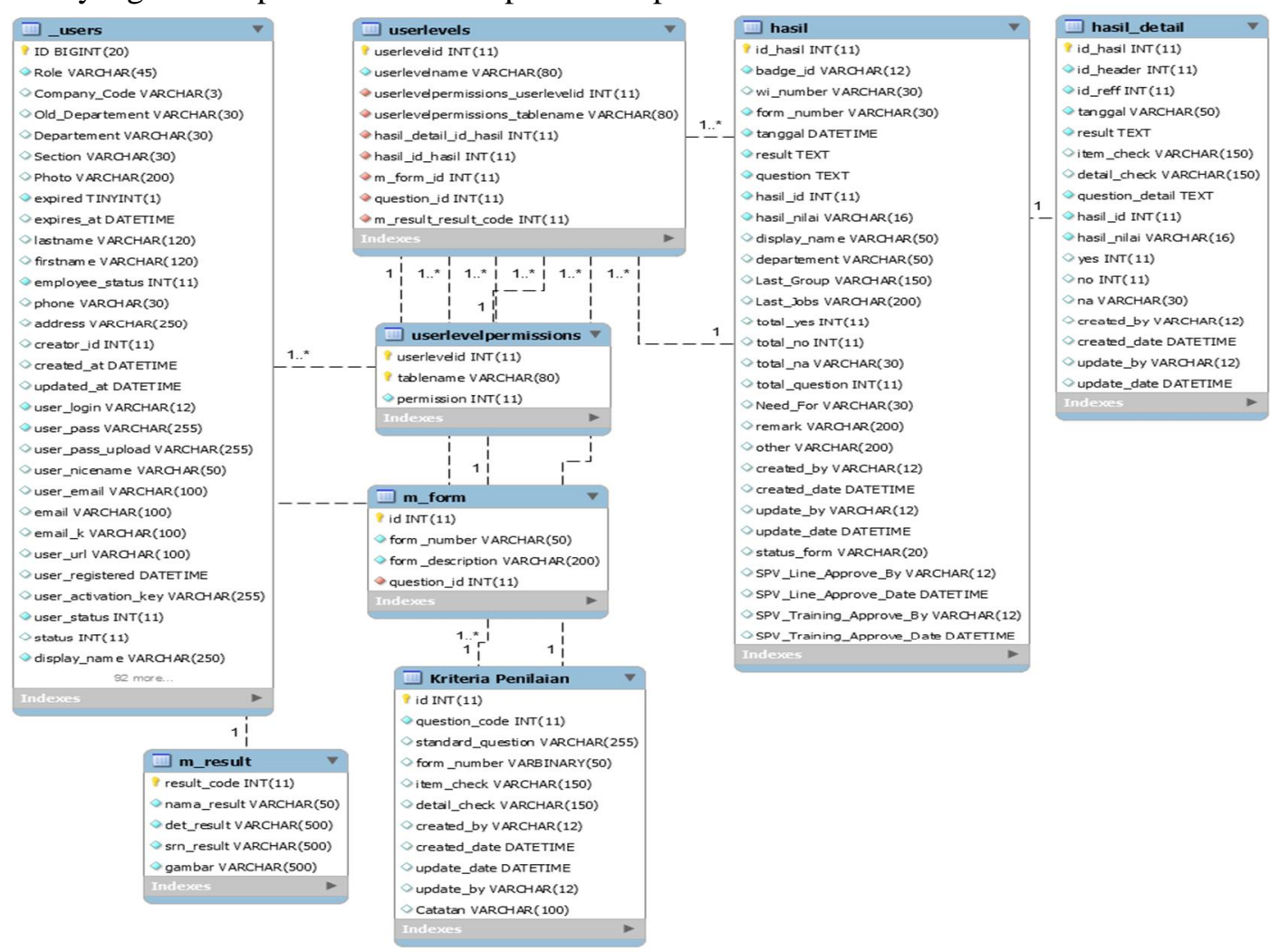

Gambar 5. ERD Penilaian Karyawan

\subsubsection{Metode SAW}

Metode SAW adalah Mencari penjumlahan terbobot dari kriteria kinerja pada setiap alternatif pada semua atribut. Metode SAW membutuhkan proses normalisasi matriks keputusan (X) ke suatu skala yang dapat diperbandingkan dengan semua rating alternatif yang ada [10]. Jika $\mathrm{j}$ adalah atribut keuntungan (benefit), maka digunakan persamaan 1 , tetapi jika $\mathrm{j}$ adalah atribut biaya (cost), maka digunakan persamaan 2. Dimana $r$ adalah rating kinerja ternormalisasi dari alternatif pada kriteria ; $i=1,2, \ldots, m$ dan $j=1,2, \ldots, n$. Nilai preferensi untuk setiap alternatif (Vi) didapatkan menggunakan persamaan 3 .

$$
\begin{gathered}
=\frac{x_{i j}}{\operatorname{Max} x_{i j}} \ldots . \\
=\frac{\operatorname{Min} x_{i j}}{x_{i j}} \ldots . \\
=\sum_{j}^{n} W_{j} R_{i j}
\end{gathered}
$$

\section{HASIL DAN PEMBAHASAN}

Implementasi merupakan suatu perwujudan atau penerapan dari rancangan sistem yang telah dibuat ke dalam suatu program sehingga fungsi dari masing-masing proses akan terlihat. Pada bagian ini dituangkan hasil dan pembahasan dari sistem yang dibuat. 


\subsection{Penentuan Kriteria Metode SAW}

Kriteria penilaian yang ditetapkan oleh perusahaan telah ditentukan diberi bobot sama rata sesuai dengan kebijakan pada perusahaan. Kriteria penilaian dapat dilihat pada tabel 1 hingga 3.

Tabel 1. Kriteria Penilaian

\begin{tabular}{|c|l|}
\hline Kriteria & \multicolumn{1}{|c|}{ Keterangan } \\
\hline K1 & $\begin{array}{l}\text { Bertanggung jawab untuk berhasil mencapai tujuan sesuai } \\
\text { tenggang waktu dengan sikap 'can do attitude'. }\end{array}$ \\
\hline K2 & $\begin{array}{l}\text { Melakukan aktivitas sampai selesai dengan dorongan energi } \\
\text { dan adanya kebutuhan untuk menuntaskan }\end{array}$ \\
\hline K3 & $\begin{array}{l}\text { Mengetahui \& memahami kebijakan dan prosedur utama, } \\
\text { termasuk budaya organisasi, misi dan visi perusahaan, hirarki } \\
\text { struktur organisasi, peran dan target kerja. }\end{array}$ \\
\hline K4 & $\begin{array}{l}\text { Bisa menyelesaikan pekerjaan melalui pendekatan formal \& } \\
\text { struktural }\end{array}$ \\
\hline K5 & $\begin{array}{l}\text { Menghormati keberagaman, dapat percaya serta menghargai } \\
\text { pendapat orang lain }\end{array}$ \\
\hline K6 & $\begin{array}{l}\text { Menunjukkan kemauan bekerja sama dengan aktif } \\
\text { berkontribusi dan berpartisipasi serta berbagi informasi yang } \\
\text { layak kepada orang lain. }\end{array}$ \\
\hline K7 & $\begin{array}{l}\text { Memeriksa keakurasian untuk memastikan pada kesempatan } \\
\text { pertama suatu hasil yang berkualitas dan berkuantitas tinggi. }\end{array}$ \\
\hline K8 & $\begin{array}{l}\text { Menyediakan dokumentasi untuk melacak progress pekerjaan } \\
\text { rutin atau proyek dan memastikan bukti pelaksanaannya }\end{array}$ \\
\hline K9 & $\begin{array}{l}\text { Kejujuran (mempertahankan nilai-nilai kebenaran, tidak } \\
\text { pernah menipu, berbohong atau sengaja menutupi } \\
\text { kesalahannya) }\end{array}$ \\
\hline K10 & $\begin{array}{l}\text { Disiplin terhadap waktu (datang tepat waktu dan tepat waktu } \\
\text { menggunakan jam istirahat) dan terhadap peraturan-peraturan } \\
\text { dan prosedur yang berlaku (selalu mentaati Peraturan dan } \\
\text { prosedur Perusahaan) }\end{array}$ \\
\hline
\end{tabular}

Tabel 2. Nilai Bobot

\begin{tabular}{|c|l|}
\hline $\begin{array}{c}\text { Range Nilai } \\
\text { (Setiap kelipatan 0,5 dibulatkan ke atas/ round up) }\end{array}$ & \multicolumn{1}{c|}{ Deskripsi } \\
\hline $4,5-5$ & Sangat Baik (dalam berprestasi) \\
\hline $4-4,4$ & Baik (dalam berprestasi) \\
\hline $3-3,9$ & Cukup (berprestasi) \\
\hline $2-2,9$ & Kurang (berpretasi) \\
\hline $1-1,9$ & Sangat Kurang (berprestasi) \\
\hline
\end{tabular}

Tabel 3. Pengurang Nilai

\begin{tabular}{|l|c|}
\hline Deskripsi & Nilai Pengurang \\
\hline Surat Teguran (ST) & 2 \\
\hline Surat Peringatan 1 (SP1) & 5 \\
\hline Surat Peringatan 2 (SP2) & 10 \\
\hline Surat Peringatan 3 (SP3) & 15 \\
\hline
\end{tabular}




\subsection{Tampilan Antarmuka Sistem}

\subsubsection{Halaman Login}

Menu login pada sistem ini berguna untuk validasi data pengguna. Sebelum masuk ke menu utama, pengguna harus menginputkan username dan kata sandinya. Setelah mengklik tombol masuk, sistem mengecek database dengan data login yang diinputkan oleh pengguna, termasuk level hak akses pengguna dalam menggunakan sistem (level administrator). Jika data yang diinputkan benar, akan masuk ke tampilan menu utama. Tampilan menu login dapat dilihat pada gambar 6.

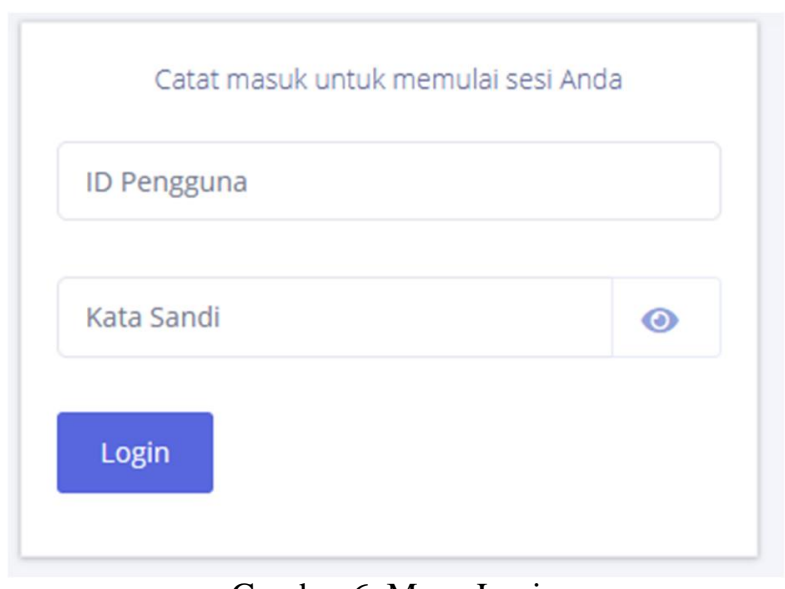

Gambar 6. Menu Login

\subsubsection{Halaman Kriteria Nilai}

Halaman kriteria nilai adalah, halaman yang berfungsi sebagai daftar/ list kriteria nilai yang menyimpan data master yang nantinya digunakan sebagai reverensi peniliaan. Pada halaman ini juga berfungsi sebagai tambah, edit dan hapus data yang dilakukan oleh HRD. Tampilan halaman kriteria nilai dapat dilihat pada gambar 7 .

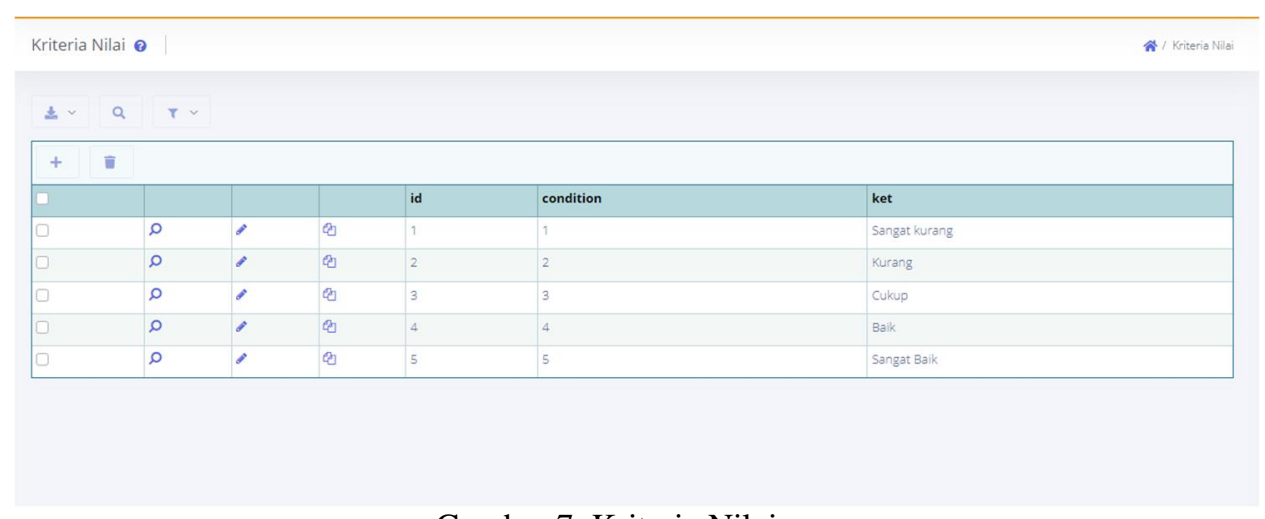

Gambar 7. Kriteria Nilai

\subsubsection{Form Penilaian}

Pada halaman ini, setalah administrator menentukan otorisasi dan hak aksesnya, penilai membuka halaman ini untuk menilai karyawan atau bawahannya langsung satu persatu, form ini digunakan untuk menilai karyawan berdasarkan metode SAW, Penilian ini dimulai dengan mengisi shift, karyawan yang akan dinilai berdasarkan NIK atau user yang telah didaftarkan pada data master karyawan/ user, berikut tampilan input penilian dapat dilihat pada gambar 8 . 


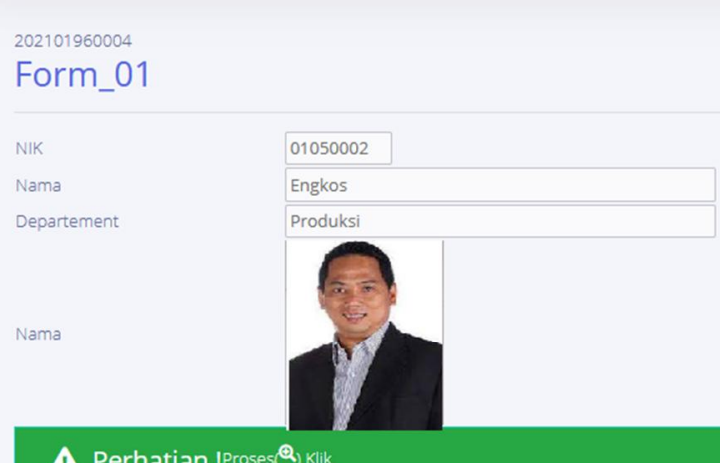

4. Perhatian !Proses $\left(Q_{\text {Klik }}\right.$

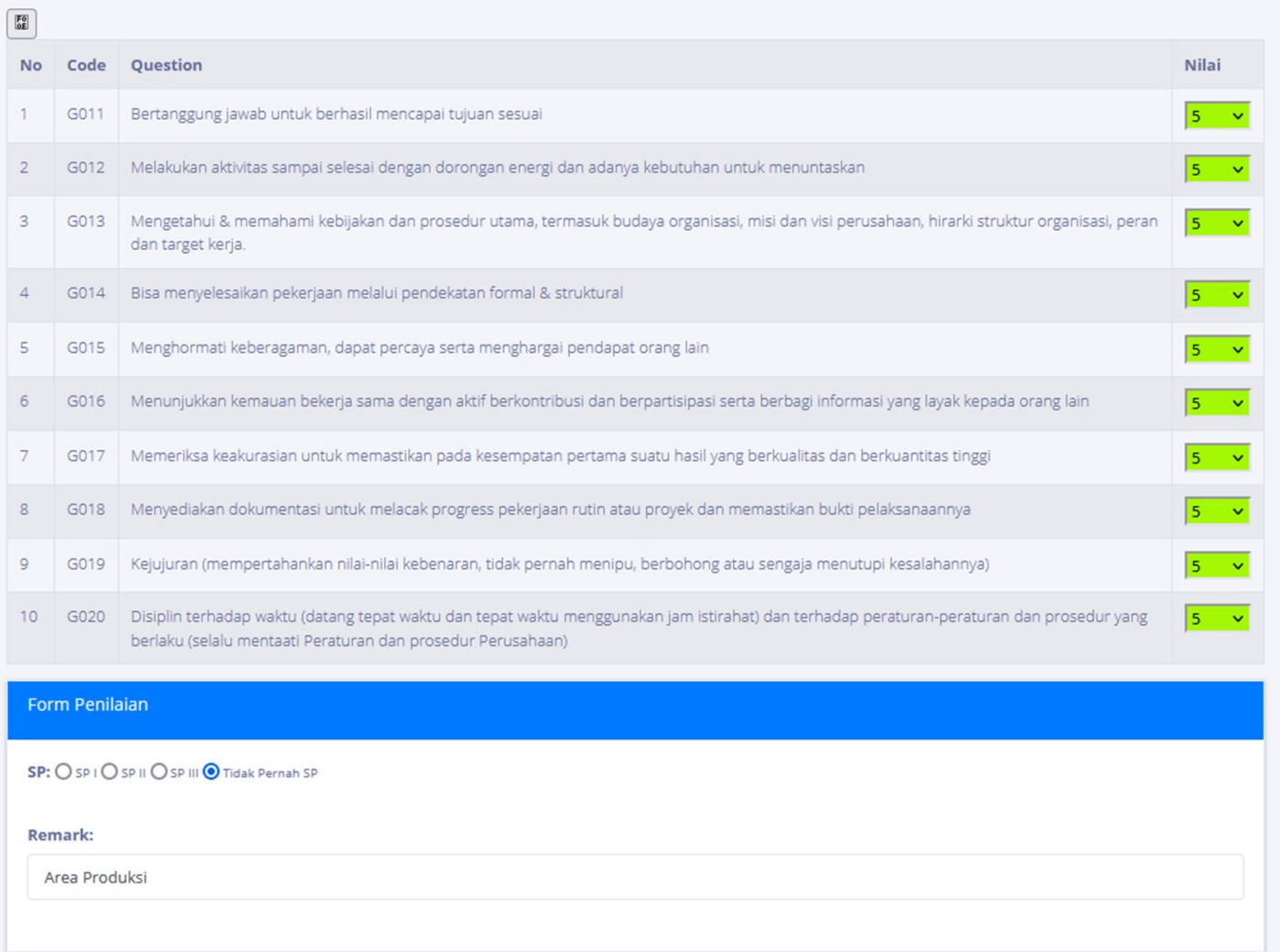

\section{Gambar 8. Form Penilaian}

\subsubsection{Halaman Summary Nilai}

Pada Halaman Summary, Karyawan dapat melihat hasil penilaian terhadap semua karyawan sesuai kriteria yang digunakan oleh perusahaan setiap tahunnya. Adapun bentuk tampilan Halaman Summary dapat dilihat pada Gambar 9, dan untuk grafik penilaian dapat dilihat pada Gambar 10. 


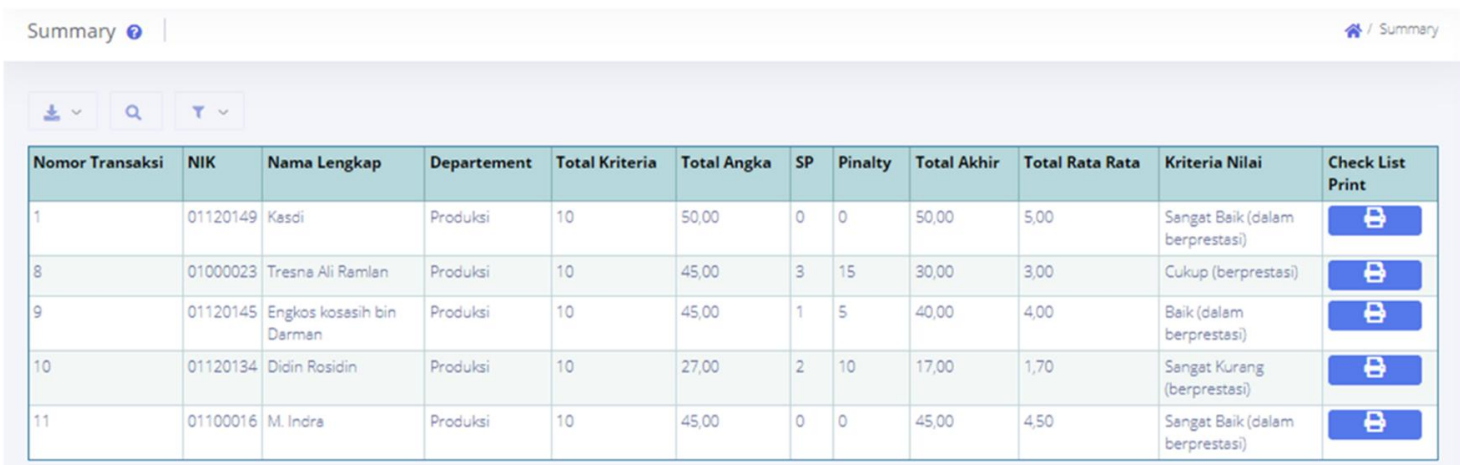

Gambar 9. Halaman Summary

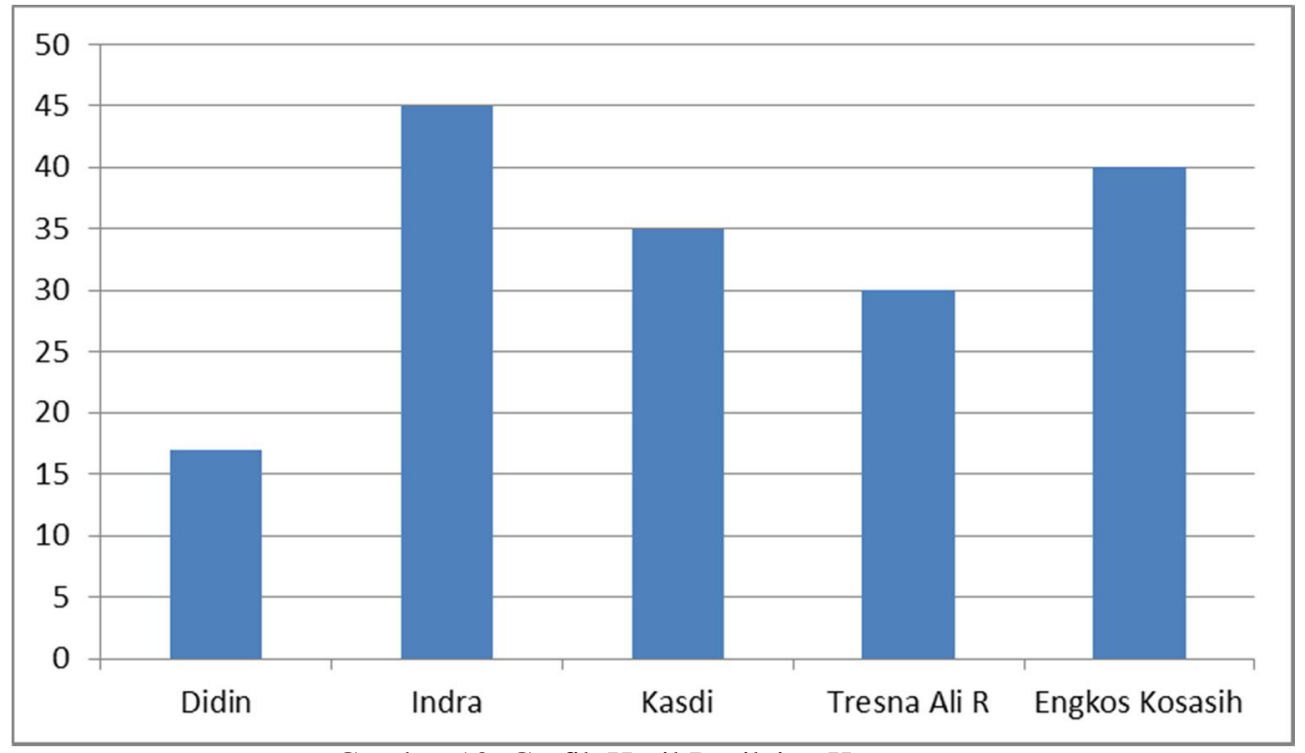

Gambar 10. Grafik Hasil Penilaian Karyawan

\section{KESIMPULAN DAN SARAN}

Penelitian ini menghasilkan sebuah sistem pendukung keputusan penilaian kinerja karyawan yang dapat digunakan untuk penentuan karyawan terbaik. Dengan demikian untuk menjadi seorang karyawan terbaik tidak hanya dilihat dari segi seberapa lamanya karyawan tersebut bekerja tetapi juga harus memiliki kinerja dan perilaku yang baik.

Permasalahan terkait transparansi dapat diatasi pada sistem yang dibuat karena karyawan dapat melihat proses perhitungan dan penilaian terhadap semua karyawan yang ada pada perusahaan.

Penelitian selanjutnya dapat menggunakan metode pendukung keputusan lainnya untuk menyempurnakan sistem pendukung keputusan ini. Dan semoga hasil dari penelitian ini dapat menjadi bahan bagi peneliti selanjutnya. 


\section{DAFTAR PUSTAKA}

[1] P. H. Mandala, 2014. "Sistem Pendukung Keputusan Pemilihan Karyawan Berprestsi di Pertamina Pengapon Semarang Dengan Metode Simple Additive Weighting,” pp. 1-7,

[2] Fajar Ilhamsyah, 2017. "Pengertian DSS (Decision Support System)," http://www.sistem-informasi.xyz/2017/08/pengertian-dss-decision-support-system.html (accessed Aug. 24, 2021).

[3] F. Rachman and A. F. Daru, 2021, "Aplikasi Sistem Pendukung Keputusan Penilaian Karyawan pada PT. GA Tiga Belas Dengan Metode Simple Additive Weighting (Application The Support System Decision Assessment Employees At PT. GA Tiga Belas With The Methods Simple Additive Weighting)," Vol. 17, No. 1, pp. 24-30.

[4] S. Abadi and F. Latifah, 2016, "Decision Support System Penilaian Kinerja Karyawan pada Perusahaan Menggunakan Metode Simple Additive Weighting," J. TAM (Technology Accept. Model., Vol. 6, pp. 37-43.

[5] Kusrini, 2010., Konsep dan Aplikasi Sistem Pendukung Keputusan. Andi, Yogyakarta.

[6] Q. Noval, Y. Handrianto, and H. Supendar, 2020, "Sistem Pendukung Keputusan Dalam Menentukan Karyawan Terbaik Menggunakan Metode Simple Additive Weighting," J. Infortech, Vol. 2, No. 1, pp. 116-121, doi: 10.31294/infortech.v2i1.8118.

[7] Sondang P. Siagian, 2014, Decision-making. Bumi Aksara.

[8] H. Hertyana, 2018, "Sistem Pendukung Keputusan Penentuan Karyawan Terbaik Menggunakan Metode SAW Studi Kasus Amik Mahaputra Riau,” Intra-Tech, Vol. 2, No. 1, pp. [Online]. 74-82, Available: https://www.journal.amikmahaputra.ac.id/index.php/JIT/article/view/27.

[9] H. Murdianto, D. M. Khairina, and H. R. Hatta, 2016, "Sistem Pendukung Keputusan Pemilihan Karyawan Terbaik Per Triwulan PT. Cahaya Fajar Kaltim PLTU Embalut Tanjung Batu Menggunakan Metode Simple Additive Weighting," Pros. SAKTI (Seminar Ilmu Komput. dan Teknol. Informasi), Vol. 1, No. 1, pp. 24-29, doi: 10.31219/osf.io/j4yva.

[10] D. Nofriansyah, 2015, Konsep Data Mining Vs Sistem Pendukung Keputusan. CV. Deeppublish, Yogyakarta. 